\title{
Depression and Systemic Lupus Erythematosus: A Case Report
}

\section{Cal SF*}

Clinical Psychologist, Doctor and Master in Medicine and Human Health, Brazil

*Corresponding author: Sílvia Fernanda Cal, Clinical Psychologist, Doctor and Master in Medicine and Human Health, Brazil, Tel: 5571334122320, Email:

\section{Case Report}

Volume 3 Issue 3

Received Date: February 23, 2018

Published Date: March 09, 2018 silviacal@uol.com.br

\section{Abstract}

This is a case report of a patient with lupus who had severe depression and underwent sessions of analytical psychotherapy for 2 years. In the psychotherapy, beside verbal expression, there was the utilization of techniques such as: amplification through drawing, painting and Sandplay. There was an improvement of depression and symptoms of lupus.

Keywords: Systemic lupus erythematosus; Depression; Psychotherapy

\section{Introduction}

Systemic lupus erythematosus (SLE) is an autoimmune disease in which neuropsychiatric symptoms are known [1], where the most prevalent is depression [2-4]. This study's objective is to report the experience of a psychotherapy with a patient with SLE assailed by severe depression.

Patient: Fifty-five-year-old woman, messianic, divorced, childless, living alone, with SLE diagnosis and a history of arterial hypertension, Raynaud's Syndrome, pulmonary interstitial fibrosis, vasculitis, with non-specific process of chronic inflammation in right lower limb, erosive esophagitis and gastritis. The Mini-Plus diagnosed major depression, dysthymia, agoraphobia, bulimia, generalized anxiety disorder, body dysmorphic disorder and alcohol abuse [5]. She attempted suicide at around 18 years old.

Intervention: Patient underwent sessions of analytical psychotherapy in a private clinic for 2 years, with weekly, 50-minute sessions where, besides verbal expression, there was the utilization of techniques such as: amplification through drawing, painting and Sandplay $[6,7]$.
Results: Patient had better quality of life, remission of depression symptoms and, interestingly, also of SLE, returning to work after being away for 12 years, due to sick leave.

\section{History of Current Disease}

Around 1985, the year her mother died, the patient presented with recurring colds, infections in several parts of her body, intense diarrhea, constant pain especially in her joints, as well as weight loss. SLE was diagnosed, besides diffuse goiter with a recommendation for surgery. As the patient was not in any condition to undergo surgery, she received radiation treatment. She then went from having hyperthyroidism to hypothyroidism.

She presented alopecia, difficulty moving and eating, falling to $37 \mathrm{~kg}(81.5 \mathrm{lb})$. The following medications were administered: immunosuppressants (25mg), antimalarial (150mg), corticoids (80 $\mathrm{mg}$ ) and thyroid hormone replacement $(150 \mathrm{mg})$, when she began to show signs of improvement. As she presented dyspnea, a neonatologist examined her and diagnosed pulmonary interstitial fibrosis, whereby she underwent surgery to remove part of her lung. 


\section{Psychology \& Psychological Research International Journal}

In the beginning of 2002, she presented vasculitis and had to be hospitalized with the risk of amputation of her right leg; both legs were causing much pain and were red, swollen, and covered in festering sores. This was treated with a monthly dose of pulse therapy with corticoids. The symptoms disappeared, where she then presented deep, painless spots.

\section{Personal and Social History}

The patient suffered sexual abuse from 9 to 15 years old, from a brother-in-law (her sister's husband), whose house she would visit. In these contacts, she discovered sexual sensations that would give her intense pleasure and her first orgasm, but at the same time she felt shame and guilt, etc.

At 18 years of age, during a new advance from her brother-in-law, they were caught in the act by her mother, who put a halt to the situation.

From then on, the patient had different relationships with men, even got engaged, but before the wedding she discovered that she "liked women." Even so, at 25, she married a cousin whom she did not love and who disgusted her. Still during her marriage, she was sexually active with women. She divorced at 32 and continued in a homosexual relationship that lasted 15 years.

The Lupus symptoms began after the death of her sister, in 1982. Years later (1989), she was violently raped by a co-worker, and recently (2007), her house was broken into by a neighbor, who also raped her.

\section{Evolution of Psychotherapy Treatment}

Psychotherapy began in April of 2006. Initially, they worked on her acceptance of her own homosexuality and the accentuated prejudice regarding this condition. There has been a marked improvement in her self-esteem. Already in the initial phase of psychotherapy, what Freud called catharsis, and regarded as confession by Jung, where secrets are revealed, reports of improvement in the SLE symptoms began to emerge.

Due to the fragilegoic structure, the psychotherapy worked on strengthening the ego. The patient developed an important bond of trust with the therapist, showing herself to be diligent, compliant, and aware of the important role her emotional conflicts had in the evolution of the illness.
Lastly, a medical board considered her capable of returning to her job, which she did, after being on leave for 12 years, receiving benefits. At her job, she is deemed an excellent employee, gaining respect and admiration from her co-workers.

\section{Discussion}

The patient developed SLE after the death of her sister, with whom she had a type of love triangle that left her feeling much guilt, and aware of having done "something wrong," but not seeing herself as having been sexually abused. During psychotherapy, it seems she was able to share this burden somewhat, name her feelings for what they were, and perceive the great hatred she nurtures toward her abuser, whom she calls "demon." In this case there was an adult and a child whose developmental level made it impossible for her to understand the nature of this sexual contact, establishing it as a relationship that violates social and family norms. Abuse within a family setting is the most frequent, with harmful consequences for the victim, when considering the affective relationship between the child and the perpetrator [8]. The abusive relationship she had with her brother-in-law seems to have interfered in the construction of her femininity and in the process of identifying with the female sex. The choice to love a man became unfeasible, since this situation was associated with a ban, sin, something dirty and guilt, etc. The attempts at having relationships with men were marked by situations of violence, abuse and misconduct, which she subconsciously sought.

The child that is abused over a long period of time tends to lose his/her self-esteem, as well as their trust in others, which can even lead to suicide attempts, as occurred in this case. Therefore, the psychological consequences of the abused child can be devastating and have a great impact on their physical and mental health, possibly leaving lifelong scars. On the other hand, childhood sexual abuse is a frequent antecedent in women seeking health care services, due to depressive symptoms and other psychiatric disorders [9]. There is also an association between childhood sexual abuse and excessive alcohol consumption, which coincides with this case study, where the patient has a long history of alcohol abuse, and between sexual abuse and suicide $[10,11]$.

The patient's psychological suffering was intense, and since one may experience the subconscious through one's body, for it conveys to us in its tremor, temperature and flush as much as in the severity it uses in seeking to hide feelings [12], and considering that body language 


\section{Psychology \& Psychological Research International Journal}

announces and condemns, in this way supplying symbols to our awareness, one may presume that SLE, in this case, was a self-destructive outlet.

A decrease in the depression and an improvement in the patient's self-esteem and self-care were made possible with the psychotherapy and the opportunity to identify and redefine the traumatic situation she had gone through. It has been ten years since she underwent assistance and follow-up, but the patient has not had relapses of the depressive symptoms or of SLE symptoms.

\section{Conclusion}

Psychotherapy may be an important tool in treating SLE, for besides being beneficial in improving depressive symptoms, self-esteem and self-care, and one's adjustment to the illness; it may even influence the progress of the disease.

\section{References}

1. Ampelas JF, Wattiaux MJ, Van Amerongen AP (2001) Psychiatric manifestations of lupus erythematosus systemic and Sjogren's syndrome. Encephale 27(6): 588-599.

2. Bachen EA, Chesney MA, Criswell LA (2009) Prevalence of mood and anxiety disorders in women with systemic lupus erythematosus. Arthritis Rheum 61(6): 822-829.

3. Cal SF, Santiago MB (2011) Prevalência da distimia e principais co-morbidades psiquiátricas em pacientes brasileiros com com lúpus eritematoso sistêmico. Rev Bahiana Saúde Pública 35(4): 859-868.

4. Nery FG, Borba EF, Viana VST, Hatch JP, Soares JC, et al. (2008) Prevalence of depressive and anxiety disorders in systemic lupus erythematosus and their association with anti-ribosomal $\mathrm{P}$ antibodies. Prog Neuropsychopharmacol Biol Psychiatry 32(3): 695700 .

5. Amorim P (2000) Mini International Neuropsychiatric Interview (MINI): validação de entrevista breve para diagnóstico de transtornos mentais. Rev Bras Psiquiatr 22(3): 106-115.

6. (1956) Sand play: Dora Kalff's sand play technique.

7. Ammann R (2002) A terapia do jogo de areia [Internet]. Paulus, editor. São Paulo: Paulus.

8. Amazarray MR, Koller SH (1998) Alguns aspectos observados no desenvolvimento de crianças vítimas de abuso sexual. Psicol Reflexão e Crítica 11(3): 559578.

9. Pfeiffer LSE (2005) Current view of sexual abuse in childhood and adolescence. J Pediatr Rio J 81(5): S197-S204.

10. Ullman SE, Starzynski LL, Long SM, Mason GE, Long LM (2008) Exploring the Relationships of Women's Sexual Assault Disclosure, Social Reactions, and Problem Drinking. J Interpers Violence 23(9): 12351257.

11. Bebbington PE, Cooper C, Minot S, Brugha TS, Jenkins R, et al. (2009) Suicide Attempts, Gender, and Sexual Abuse: Data from the 2000 British Psychiatric Morbidity Survey. Am J Psychiatry 166(10): 11351140.

12. Reis MR (2002) O Corpo Como Expressão De Arquétipos. Junguiana - Rev latino-americana da Soc Bras Psicol Analítica pp: 20. 